\title{
Relationship Between Social Media Performance and Brand Image in Digital Branding Proces: Netflix Turkey
}

\author{
Şeyda OK iD a Mehmet BAŞ iD b \\ a OSTIM Technical University, Faculty of Economics and Administrative Sciences, Department of Marketing, Ankara, Turkey \\ seyda.ok@ostimteknik.edu.tr \\ b Ankara Hacı Bayram Veli University, Faculty of Economics and Administrative Sciences, Department of Business, Ankara, Turkey \\ mehmet.bas@hbv.edu.tr
}

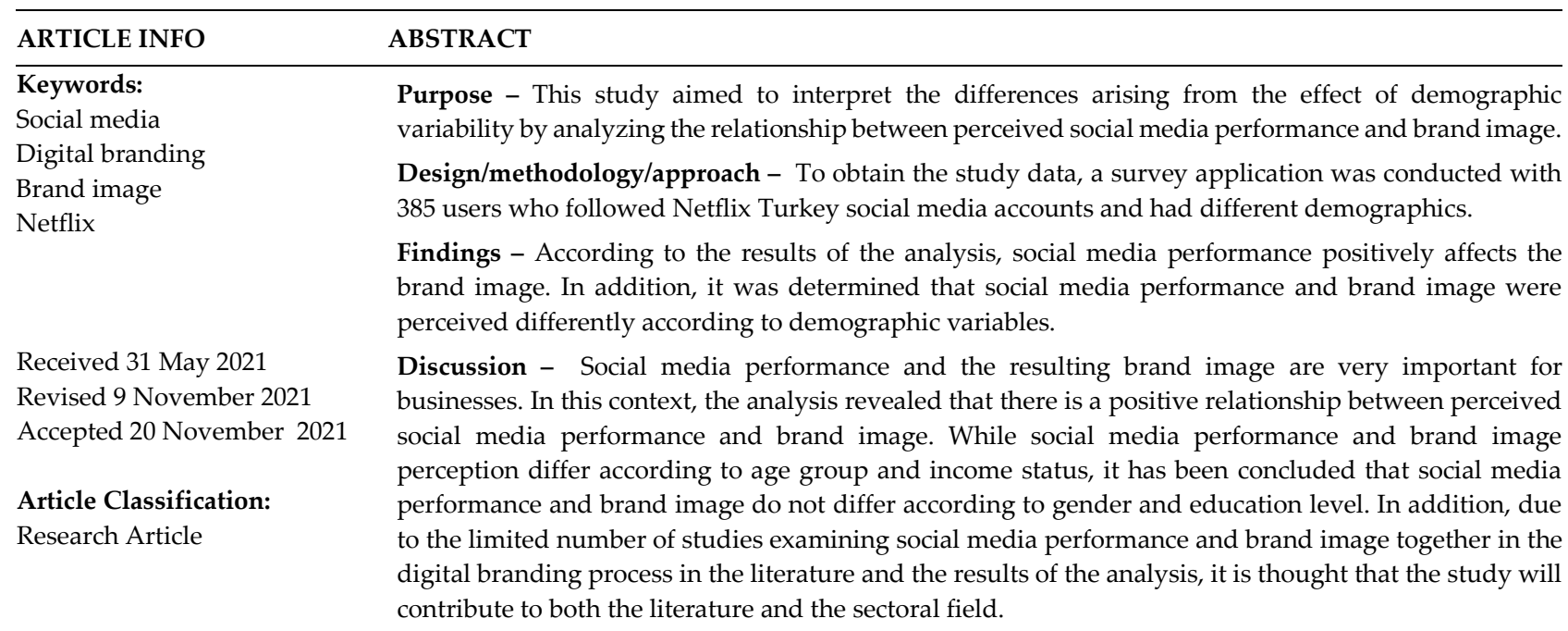

\section{Introduction}

As a result of the developments in today's communication technologies, the concepts of digitalization and social media have emerged. In addition to the fact that people prefer social media channels for different purposes, communication has started to digitize and the use of social media, which is one of these tools, has led to various businesses and brands taking their place and operating in this area for marketing activities.

Digital channels and assets are used to communicate a brand's position (or purpose) as part of multichannel brand communication or interaction programs.

Unlike digital marketing, branding aims to establish links between consumers and the product or service offered to ensure brand recognition in the digital world. In short, the goal of digital branding today is not to increase sales, but to increase brand awareness, image, and style and in return to ensure long-term customer loyalty.

Brands that provide the opportunity to meet and interact with consumers directly through social media can carry out communication activities at almost no cost to promote their goods and services and strengthen their brand image. Currently, it has been considered important to research this area, depending on the use of social media is indispensable for the brand and brand image. 


\section{Conceptual Framework}

\section{Brand}

\section{Brand concept}

To distinguish a product or object from a brand like the concept, according to the American Marketing Association's definition: "determining or identifying a vendor's product or service as distinct from other sellers, name, phrase, design, symbol, or any other features." (Hatch \& Schutz, 2011).

\section{Brand image}

Brand value is also evaluated as a total reflection of the brand image and the tangible and intangible assets of the brand (Aktepe \& Baş, 2008). According to Keller (1993), a brand image is consumers' perception of a brand that reflects brand associations in consumers' memory. It involves consumers' thoughts and feelings toward the brand (Roy \& Banerjee, 2007), or their mental image about a brand that makes it unique in comparison to other brands (Faircloth, 2005). Brand images include consumers' knowledge and beliefs about various products of the brand and nonproduct features. They represent the personal symbolism that consumers associate with the brand, which includes all descriptive and evaluative information about the brand (Iversen \& Hem, 2008). If consumers have a favorable brand image, their message has a stronger influence in comparison to other brands (Hsieh, 2008).

Kotler (2000: 180) states that people's beliefs about the brand create the image of the brand. Perceptions and beliefs about the brand directly affect the profitability of the brand and therefore the continuity of the company. Brand image plays an important role in the development of a brand. Because the brand image, which is related to the reputation and reliability of the brand, then turns into "guidelines" that the consumer audience refers to try or use a product or service. Trial and consumption for brands by the consumer result leads to a specific experience (brand experience) that will determine whether the consumer will be loyal to the brand or simply an opportunist (easy to switch to another brand). Brand image is a representation of the general perception consisting of knowledge and belief about the brand. Brand image is closely related to attitudes and beliefs that create a choice (preference) for a brand (Wijaya, 2013: 58).

\section{The importance of brand image}

Brand image is very important for businesses, not only does it leave an unforgettable impression on consumers, but it also allows your customers to know what to expect from your company. It's a way to separate yourself from competitors and make it clear what you're offering. Your brand is built to be a true representation of who you are as a business and how you want to be perceived. The brand image is highly critical because of its impact on the business. Brand image can change the way people perceive your brand, increasing your preference and brand awareness. The main reason why a brand image is important to a business is that it affects how a business is recognized and perceived by consumers.

In today's conditions, one of the channels that businesses use to create and manage brand image is social media. As part of the social media strategies of brands, the importance of mutual communication increases the value of the corporate image. Social media is a virtual communication environment in which consumers can receive instant feedback, transfer information, and brands can create images. During communication established on social media, the business can create the brand image it wants by managing the perception it wants to create on the opposite side with the communication strategies it uses. Creating a brand image requires an informed management process that needs to be well managed. Businesses must be aware of this.

\section{Digital branding}

Services carried out for digital branding aim to increase brand awareness, explain the mission and vision of the business and develop and strengthen customer loyalty.

Digital branding is a form of branding and brand management. It takes the traditional concept of branding and translates it into the digital world. It leverages the power of the internet as well as digital marketing strategies to strengthen a brand's online profile. 
Branding in the digital surroundings emphasizes the point of branding in a fresh means. It is not only a logo, slogan, sound, or color, however, it is the whole practice clients buy on the internet in any case of provided that it is made by the brand or not (Rowles 2014, 11).

The purpose of digital branding is to offer a worth suggestion that is genuine and distinct to assist clients to understand the firm as a complete. Digital branding investigates occupant profiles and buys processes, so it can structure cognizance and credit owing to precious meaning in a measurable method (Rowles 2014, 21).

Graham (2008) emphasized that the marketers are not in control of the introduction of their brands to consumers, nor do they have the loudest voice. The competitor's exploitation of digital branding is not limited to the brand's adjoint to their outlets. Hankinson \& Cowking (2005) emphasize that the sophistication of brands is reflected in the form of traditional marketing, right along with side media platforms, submits a certain set of ways for appealing the consumers.

What our customers think about us is more important than what we think about our business. Our digital branding efforts mean a lot about who we are and what value we provide to our customers, potential customers, partners, members, or consumers.

Building a strong digital branding strategy provides great opportunities for businesses to compete, but it can have negative consequences for your brand if neglected (Tolon,Zengin,2016:31).

\section{Creating digital brand identity}

A brand's identity consists of characteristics and properties of the brand that adhere to the genuine set of associations that a company desires to design and sustain (Alselm \& Kostelijk, 2008; Esch, 2008). Brand identity aids design connections between the company and consumers (Fournier, 1998), and can conduct to sensations of brand personality (Aaker, 1997; Aaker, Fournier, \& Brasel, 2004).

Creating a corporate identity is the first and priority issue you should consider for branding in the digital age we are in. One of the most important elements of an organization, company, or brand is to create a corporate identity. Corporate identity and branding are a process that needs to be followed very carefully.

The stability of corporate identity on digital platforms is one of the important elements of the branding process. For this reason, the stages of creating brand identity in the digital branding process of institutions are included. Digital institutions as part of the identity formation process; provide content, search, engine optimization, mobile compatibility, social media communication, rich media, e-commerce, e-mail marketing, and customer interactions are among the factors that need to be carefully evaluated.

7 basic elements should be considered while creating a corporate identity;

\section{- Customer}

Traditionally, the customer is the end-user of our product. The customer emerges at the last point in the chain of activities related to making the product usable and offering it to consumption.

In the digital sense, it is necessary to examine what customers are looking for, which devices, when they use, and which social networks they prefer, as well as how often they interact with websites and applications, and make decisions by evaluating the results of these reviews. Your corporate identity must be able to be transferred end-to-end through your online brand.

\section{- Identity}

Brand identity is the element created by brand managers that gives direction, purpose, and meaning to the brand. Just as an identity card saves people from being human beings and gives them a name, brand identity is also one of the most important factors that distinguish the brand from other brands.

\section{- Competitors}

Thanks to digital channels, companies can be examined more transparent and in detail than ever before. Some points that can be examined while competitor analysis is so easy; competitors' positions in search results, sample applications, user experiences of web pages, and e-mail addresses. Predictions can be made on what 
competitors are offering, how they communicate, what the experience is like, and where they are focusing on customers and products online.

With competitor analysis, the social networks where competitors are located and focused can be seen, the competition volume of search keywords between competitors can be examined, and the content strategy they use to create more interaction can be learned.

- Message

Messages that support the product, service, or customer value are necessary to establish the identity and ensure that customers understand this in a short time. Brand messages given on digital platforms should all be in the same tone and consistency, and the narrative style should be natural and coincide with the brand image.

\section{- Location}

In traditional definition, the business location is the place where the business decides to carry out its operations. The choice of location has a significant impact on the costs and profitability of the business.

With the introduction of the internet into our lives, the binding power of distances has become very weak. Today, companies can open their doors to potential customers anywhere in the world, regardless of their place of establishment, through their websites. They can sell through the e-commerce system and send the sold product to the customer's door. These new possibilities rewrote the location description for companies.

Brand awareness and responsibility have become more important with the use of smartphones. Locationbased applications make it possible for customers to find companies more easily. Mobile devices make it easy for customers to share their product or service purchase experience. Such activities add value to the brand by creating a marketing effect of word of mouth.

- Product

The concept of the product is one of the most fundamental elements of the marketing mix. It is divided into two in terms of being touch and untouchable and can mean different things to different people.

In the branding process, products are seen as the main message and positioning element of the brands. Some of the activities that will help brands provide action and can be used for the promotion of products;

a. Description of the product with video content.

b. Interactive applications to be developed to examine the product interactively.

c. Sharing product features and facilities through social media.

$\mathrm{d}$ "Augmented Reality" applications to be developed for use in mobile vehicles.

e. Real-time communication based on user input.

We see that brands bring together a personalized product experience with their customers on online platforms, using tactics to meet customer expectations, surprise them and be different from their competitors.

- Team

How people understand and communicate the promises of the brand in an organization is important for the progress of branding. It takes time to recruit, train and supervise the right people. Your team is crucial to getting the brand message right because a digital brand communication strategy is nothing without content.

\section{Social Media}

\section{Definition of social media and related concepts}

According to Tuten \& Solomon (2014: 2), "social media are the online means of communication, collaboration, conveyance and cultivation among interconnected and interdependent networks of people, communities, and organizations enhanced by technological capabilities and mobility."

Social Media (SM) consists of various internet-based applications that build on the foundations of Web 2.0 (Laroche, Habibi, \& Richard,2013), empowering online communities to share individual content through a representation of personal identities and interests, allowing for real-time, two-way communication. Web 2.0 has enabled the easier and faster circulation of information, referred to as a "demand-pull and supply push 
for knowledge" via different forms of social networks (Liburd, 2012). The management of a brand's social media tools is now a part of the brand image (Aktepe \& Ertürk, 2020).

\section{Social media tools}

Social media platforms that create social media with applications implemented and combined with Web 2.0 technology can be defined as technological software that creates sharing and interaction between people and communities (Fisk, 2009).

A Social Media Platform is defined as a web-based and mobile-based Internet Application that allows the creation, access, and exchange of user-generated content. Commonly used social media tools include Facebook, Instagram, and Twitter (Penni, 2017). Social media tools can be classified as blogs, wikis, micro blogs, media sharing sites, social networking sites, social bookmarking sites, podcasts, virtual worlds, online communities (Yanar\&Y1lmaz,2017).

Facebook was founded by Mark Zuckerberg in 2004 as a social networking site exclusively for Harvard University students. Mark Zuckerberg's goal was to make the world a more open and connected place. Participants had to have an e-mail address with the extension "Harvard Edu" to connect to Facebook (Okur \& Özkul, 2015).

Instagram, on the other hand, provides users with a platform to capture and share their moments through a series of images and videos (Hu et al., 2014). It is a fast-growing and developing social networking site with photo-sharing, video-sharing, and social networking services online and on smartphones. The idea behind the site is to share photos and videos using a hashtag, and this hashtag (\#) is so that other users can find photos (Sheldon \& Bryant, 2016). Finally, Twitter was founded in 2006 by Jack Dorsey and partners. Twitter is a social network where users can write posts called "tweets" (tweets), which are limited to 140 characters. It was one of the most used internet tools in 2013. Twitter is a service that contains short, clear, clear statements that can be created and perceived by anyone, where people can constantly communicate by sending messages faster and more often (Weller et al., 2014). Over time, while the use of social media has taken a large place in the lives of many people, it has also become the channels that users need in many subjects (Akylldiz\&Yılmaz, 2020).

\section{Social media and brand relationship}

The relationships organizations can manifest between customers and their brands have become an important focus in marketing (Fournier, 1998; Fournier \& Avery, 2011; Fournier, Dobscha, \& Mick, 1998). The win-win of consumer-brand relationships is that consumers derive satisfaction through greater attachment to brands and that firms that better understand and respond to customer needs generate more brand loyalty and profitability. Achieve these goals requires more connections and interactions between consumers and brands to foster meaningful relationships between them.

As interest in the brand-building benefits of social media use grows, more research is needed to guide marketers in a digital world. Since a brand relationship is often fostered and progressed gradually, the research focus should be extended from superficial social media presence (e.g., yes or no) to more in-depth dimensions of social media interaction (e.g., frequency and amount). Social media interaction refers to a consumer's proactive engagement with the brand on social media platforms such as following, replying, tweeting, sharing, liking, participating, and so on. Consumers' proactive interaction with the brand on social media can be viewed as "a customer's level of cognitive, emotional and behavioral investment in specific brand interactions" (Hollebeek, 2011).

Social media platforms, which provide rich content for brands, are a digital space where the target audience is active. According to Aaker, this digital space is an effective force for brands and brand development: (Aaker, 2015). Advantages of brands in the digital space are listed as follows;

- Allows participation: a participating target audience will be more prone to listening, learning, believing, and changing behavior than people who passively encounter advertising.

- Ensures that the content is rich and deep: social media is not limiting in terms of content, it can contain a large amount of information.

- Goal watchers: in the digital field, even individual goals can be observed. 
- Gives confidence: because the sales target is less visible, communication in the digital space gives a higher level of confidence.

\section{Method}

Research paper, Ankara Hacı Bayram Veli University Ethics Commission dated 24.03.2021, issue: E-11054618302.08.01-16496, 03 was discussed at the meeting and it was unanimously decided that there is no ethical objection to the work of the person concerned, provided that permission is obtained from the planned places.

\section{Subject of research}

The research examines the relationship between perceived social media performance and brand image. Netflix Turkey brand was discussed in the research. The reason Netflix Turkey was chosen as a brand is that this brand uses social media effectively and is a digital brand. The problem of the research is to determine the impact of the activities carried out by brands through social media on the brand and brand image.

\section{Purpose and importance of research}

For brands, being on social media platforms is very important in terms of being able to communicate directly with consumers, direct consumer acquisition and image correctly, maintain their assets and create a competitive advantage.

Today, almost all of the brands, without distinguishing the sector with the point where technology comes, have started to use this medium in their marketing strategies by operating in the digital world offered by technology. In this context, Netflix Turkey's social media performance with users is aimed to reveal the relationship between the brand image.

The main aim of the research is to determine whether the communication strategies carried out by brands through social media affect consumers ' perceptions of the brand and brand image positively or negatively.

\section{Research Model}

In this research, with the sub-dimensions of page applications, entertainment applications, informative applications, customer relations applications, and word of mouth; The relationship between the single subdimension brand image in the brand image scale was revealed. In addition, it was investigated whether each sub-dimension showed a significant difference in terms of gender, age, education status, and income status demographic characteristics in the first part of the questionnaire, as well as the average time spent on social media platforms and the change in the perspective of what was shared on social media platforms.

Figure 1. The Research Model

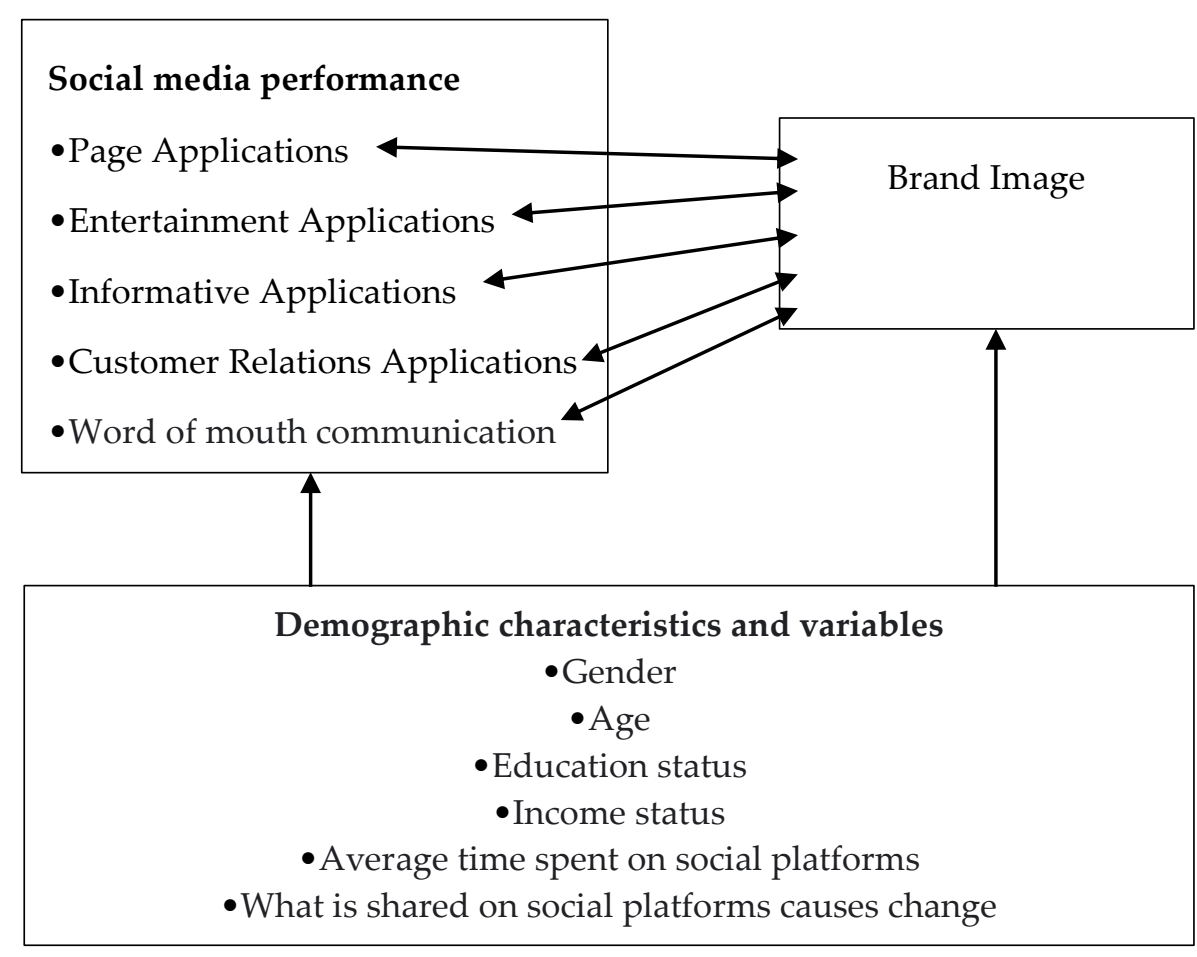




\section{Hypotheses of research}

The main purpose of the research is to determine whether there is a significant relationship between perceived social media performance and brand image. The sub-hypotheses are to determine whether the perceived social media performance and brand image differ according to the demographic characteristics of the participants. For these purposes, the hypotheses were formed as follows;

H1: There is a significant relationship between perceived social media performance and brand image.

H2: Perceived social media performance varies by gender.

H3: Perceived social media performance varies by age group.

H4: Perceived social media performance varies according to education level.

H5: Perceived social media performance varies according to income level.

H6: Brand image varies by gender.

H7: Brand image varies according to age groups.

H8: Brand image varies according to education level.

H9: Brand image varies according to revenue level.

\section{Methodology of research}

2 scales were used in the study. The first scale is the "perceived social media performance scale" developed by Kim and Ko (2012). In the second, the "brand image scale", which was prepared in the type of Likert scale consisting of 8 items, developed by Sönmezoğlu (2015), was used to measure the participants ' views on the brand image of Netflix Turkey.

\section{Population and sample}

The main focus of the research is social media users with different demographics who follow Netflix Turkey social media accounts. In the study, the easy sampling method was preferred from non-random sampling methods. In total, 385 social media users participated in the survey and all surveys were evaluated.

\section{Data collection tools}

Survey application was carried out as a data collection method. While creating the survey questions, academic studies about perceived social media performance and brand image were evaluated and finalized to determine the income level, age group, and average daily time spent on social media. The questionnaire consists of three parts. The first part of the survey form contains questions created to determine the demographic characteristics of respondents and their habits of using social media platforms. The second part includes the scale of the perceived social media platform. In the third chapter, questions are given that measure the brand image of Netflix Turkey.

\section{Analysis of the data}

The SPSS Statistics 23 program was used for the analysis of the data obtained. Before proceeding to the analysis of the data obtained from the scale, the reliability and validity of the scale were first analyzed. Descriptive statistical methods were used when analyzing survey questions. The methods used are Factor Analysis, correlation analysis, ANOVA, T-Test, and the results obtained are expressed in tables and graphs. 


\section{Findings}

Statistics for demographic variables are presented in Table 1.

Table 1. Demographic Characteristics of Participants

\begin{tabular}{|l|c|c|}
\hline Gender & N & \% \\
\hline Woman & 184 & 47.8 \\
\hline Man & 201 & 52.2 \\
\hline Age & & 27.5 \\
\hline $18-25$ & 106 & 40.0 \\
\hline $25-32$ & 154 & 32.5 \\
\hline 32 and above & 125 & \\
\hline Education & & 10.4 \\
\hline High school & 40 & 5.5 \\
\hline Associate's degree & 21 & 60.5 \\
\hline Bachelor's degree & 233 & 23.6 \\
\hline Postgraduate & 91 & \\
\hline Income & & 14.8 \\
\hline 2000 TL and below & 57 & 26.5 \\
\hline 2000 TL and 4000 TL & 102 & 27.3 \\
\hline 4000 TL and 6000 TL & 105 & 15.6 \\
\hline 6000 TL and 8000 TL & 60 & 6.5 \\
\hline 8000 TL and 10.000 TL & 25 & 9.4 \\
\hline 10.000 TL and above & 36 & \\
\hline
\end{tabular}

Of the participants in the study, $47.8 \%$ were women and $52.2 \%$ were men. $60.5 \%$ of the participants received a bachelor's degree and $23.6 \%$ received a postgraduate degree. $40.0 \%$ of respondents were between the ages of 25-32. 26.5\% have an income of 2,000 TL- 4,000 TL and 27.3\% have an income of 4,000 TL- 6,000 TL.

Table 2. Frequency Distributions of The Average Time That Participants Spent on Social Media Platforms

\begin{tabular}{|l|c|c|}
\hline What is the average daily time you spend on social media platforms & $\mathbf{N}$ & $\mathbf{\%}$ \\
\hline Less than 1 hour & 56 & 14.5 \\
\hline 1-3 hours & 202 & 52.5 \\
\hline 3-5 hours & 92 & 23.9 \\
\hline 5-7 hours & 19 & 4.9 \\
\hline 7 hours and above & 6 & 4.2 \\
\hline
\end{tabular}

$52.5 \%$ of participants were between $1-3$ hours, and $23.9 \%$ had an average time spent on social media of $3-5$ hours.

Table 3. Frequency Distributions of What Is Shared on Social Media to Change The Perspective of Participants in The Study

\begin{tabular}{|l|c|c|}
\hline $\begin{array}{l}\text { Do brand-related content and shares on social media platforms cause a } \\
\text { change in your view of the brand ? }\end{array}$ & $\mathbf{n}$ & $\mathbf{\%}$ \\
\hline Yes & 268 & 69.6 \\
\hline No & 21 & 5.5 \\
\hline Sometimes & 96 & 24.9 \\
\hline
\end{tabular}

$69.6 \%$ of respondents stated that brand-related content, comments, or shares on social media platforms caused a change in their perspective on that brand. 
Ş. Ok - M. Baş 13/4 (2021) 3858-3872

Table 4. Perceived Social Media Performance Scale Reliability Analysis

\begin{tabular}{|c|c|c|c|c|c|}
\hline References & $\begin{array}{l}\text { Factor } 1 \\
\text { Entertainment }\end{array}$ & $\begin{array}{l}\text { Factor } 2 \\
\text { Interaction }\end{array}$ & $\begin{array}{l}\text { Factor } 3 \\
\text { Trend }\end{array}$ & $\begin{array}{l}\text { Factor } 4 \\
\text { Customization }\end{array}$ & $\begin{array}{c}\text { Factor } 5 \\
\text { Word of } \\
\text { mouth }\end{array}$ \\
\hline $\begin{array}{l}\text { Netflix Turkey's social media } \\
\text { network is fun to use }\end{array}$ & 0,80 & & & & \\
\hline $\begin{array}{l}\text { The content contained within } \\
\text { Netflix Turkey's social media } \\
\text { network is of interest. }\end{array}$ & 0,83 & & & & \\
\hline $\begin{array}{l}\text { Netflix Turkey's social media } \\
\text { networks allow the brand to } \\
\text { share information with other } \\
\text { consumers. }\end{array}$ & & 0.76 & & & \\
\hline $\begin{array}{l}\text { It is possible to talk or } \\
\text { exchange ideas with other } \\
\text { consumers on Netflix Turkey's } \\
\text { social media network. }\end{array}$ & & 0,58 & & & \\
\hline $\begin{array}{l}\text { It's easy for me to share my } \\
\text { ideas on Netflix Turkey's social } \\
\text { media network. }\end{array}$ & & 0.66 & & & \\
\hline $\begin{array}{l}\text { Content on Netflix Turkey's } \\
\text { social media network is the } \\
\text { latest information. }\end{array}$ & & & 0,78 & & \\
\hline $\begin{array}{l}\text { Using Netflix Turkey's social } \\
\text { media network is quite } \\
\text { fashionable. }\end{array}$ & & & 0,80 & & \\
\hline $\begin{array}{l}\text { Netflix Turkey's social media } \\
\text { network provides the ability to } \\
\text { search for information } \\
\text { organized according to needs. }\end{array}$ & & & & 0,73 & \\
\hline $\begin{array}{l}\text { Netflix Turkey 's social media } \\
\text { network provides personalized } \\
\text { service. }\end{array}$ & & & & 0,80 & \\
\hline $\begin{array}{l}\text { I can transfer the information I } \\
\text { want to transfer to my friends } \\
\text { about Netflix Turkey from the } \\
\text { social media networks of } \\
\text { Netflix Turkey. }\end{array}$ & & & & & 0,68 \\
\hline $\begin{array}{l}\text { I would like to upload content } \\
\text { obtained from Netflix Turkey's } \\
\text { social media networks to my } \\
\text { own blog or micro blogs. }\end{array}$ & & & & & 0,75 \\
\hline Cronbach's Alpha & 0,801 & 0,642 & 0,790 & 0,781 & 0,701 \\
\hline
\end{tabular}

According to the table, participants can talk to other consumers or exchange ideas on Netflix Turkey's social media network with a value of 0.58 ."His statement has been. "The content contained in Netflix Turkey's social media network is interesting, " said the statement, which was the most attended by participants with a value of 0.83 ."his statement has been. The reliability value $(\alpha)$ of the scale was found to be 0.898 . 
Ş. Ok - M. Baş 13/4 (2021) 3858-3872

Table 5. Perceived Social Media Performance Scale KMO and Barlett Test

\begin{tabular}{|ll|l|}
\hline Kaiser Meyer- Olkin Test &, 914 \\
\hline Barlett Test & Chi- square & 2655,635 \\
& Degree of freedom & 55 \\
\hline & Significance &, 000 \\
\hline
\end{tabular}

Determining the KMO value as ,914 according to the results in Table 5 results in the appropriate distribution of factor loads on the perceived social media performance scale

Table 6. Brand Image Scale Factor Analysis

\begin{tabular}{|l|c|}
\hline References & Cronbach's Alpha \\
\hline 1.Netflix Turkey expresses difference to me & 0,81 \\
\hline 2. Netflix Turkey reminds me of quality. & 0,85 \\
\hline 3. Netflix Turkey expresses strength to me. & 0,76 \\
\hline 4. "Popularity" is one of the concepts that best describes Netflix Turkey. & 0,89 \\
\hline 5. Compared to other brands, I show a high reputation to Netflix Turkey. & 0,88 \\
\hline 6. Netflix Turkey's status is higher than that of competing brands. & 0,81 \\
\hline 7.Netflix Turkey is the leading brand in its category. & 0,78 \\
\hline 8.Netflix Turkey is privileged. & 0,77 \\
\hline
\end{tabular}

According to the table, the least agreed statement of the participants with a value of 0.76 is "Netflix Turkey means power to me." has been the statement. "Popularity" is one of the concepts that best describes Netflix Turkey with a value of 0.89 . The reliability value $(\alpha)$ of the scale was found to be 0.943 .

Table 7. Brand Image Scale KMO and Barlett Test

\begin{tabular}{|c|c|c|}
\hline Kaiser Meyer- Olki & & ,921 \\
\hline \multicolumn{2}{|c|}{$\begin{array}{ll}\text { Barlett Test } & \text { Chi- square } \\
\text { Degree of freedom } & \end{array}$} & $\begin{array}{l}2735,355 \\
28\end{array}$ \\
\hline & Significance & ,000 \\
\hline
\end{tabular}

Determining the KMO value as ,921 according to the results obtained in Table 7 gives the result that the factor loads in the brand image scale are distributed appropriately.

Table 8. Correlation Analysis of Perceived Social Media Performance and Brand Image

\begin{tabular}{|ll|c|c|}
\hline & & $\begin{array}{l}\text { Perceived Social Media } \\
\text { Performance }\end{array}$ & $\begin{array}{l}\text { Brand } \\
\text { İmage }\end{array}$ \\
\hline Perceived Social Media Performance & Pearson Correlation & 1 & $\begin{array}{c}, 823^{* *} \\
\\
\end{array}$ \\
& Sig. (2- tailed) & & 380 \\
N & Pearson Correlation &, $823^{* *}$ & 1 \\
\hline Sig. (2- tailed) &, 000 & 385 \\
& N & 385 & 385 \\
\hline
\end{tabular}

Since the Pearson correlation coefficient in Table 8 is determined as 0.823 , it is seen that there is a strong and positive relationship between the two variables. According to these results, the H1 hypothesis was confirmed.

Table 9. Perceived Social Media Performance and Gender T Test

\begin{tabular}{|c|c|c|c|c|c|}
\hline Gender & $\mathbf{N}$ & Average & Sta. deviation & $\mathbf{T}$ & $\mathbf{P}$ \\
\hline Woman & 184 & 3,71 & 0,9848 & $-1,660$ & $0,061^{*}$ \\
\hline Man & 201 & 3,90 & 0,9590 & & \\
\hline
\end{tabular}

According to Table 9, since the value of $(p)$ is greater than 0.05 , no significant differentiation was detected between perceived social media performance and gender. According to these results, the H2 hypothesis was rejected. 
Table 10. Perceived Social Media Performance and Age Groups ANOVA Test

\begin{tabular}{|c|c|c|c|c|c|}
\hline Age & N & Average & Sta. deviation & F & P \\
\hline $18-25$ & 106 & 3,52 & 1,13 & 9,418 & $0,032^{*}$ \\
\hline $25-32$ & 154 & 3,82 & 1,19 & & \\
\hline 32 and above & 125 & 4,06 & 1,29 & & \\
\hline
\end{tabular}

According to the ANOVA test data, the $p$ value (significance) was found to be $0.032<0.05$. According to these results, a significant difference was found between the age groups of the participants and their perceived social media performance. When the Tukey test was examined to determine which age variables caused this difference; Netflix Turkey social media performance perceptions of participants aged 32 and over were found to be higher than other age groups. According to these results, hypothesis $\mathrm{H} 3$ was confirmed.

Table 11. Perceived Social Media Performance and Education Status ANOVA Test

\begin{tabular}{|c|c|c|c|c|c|}
\hline Education Status & N & Average & Sta. deviation & F & P \\
\hline High school & 40 & 3,64 & 0,89 & 1,480 & $0,062^{*}$ \\
\hline Associate's degree & 21 & 3,82 & 0,95 & & \\
\hline Bachelor's degree & 233 & 3,81 & 0,92 & & \\
\hline Postgraduate & 91 & 3,45 & 1,02 & & \\
\hline
\end{tabular}

According to the ANOVA test data, the p-value was found to be $0.062>0.05$. According to the data obtained, it was determined that there was no significant difference between the educational status of the participants and the perceived social media performance. According to these results, the H4 hypothesis was rejected.

Table 12. Perceived Social Media Performance and Income Level ANOVA Test

\begin{tabular}{|c|c|c|c|c|c|}
\hline Income Level & N & Average & Sta. deviation & F & P \\
\hline 2000 TL and below & 57 & 3,43 & 1,15 & 10,860 & $0,040^{*}$ \\
\hline 2000 TL and 4000 TL & 102 & 3,91 & 1,07 & & \\
\hline 4000 TL and 6000 TL & 105 & 4,09 & 1,04 & & \\
\hline 6000 TL and 8000 TL & 60 & 3,80 & 1,10 & & \\
\hline 8000 TL and 10.000 TL & 25 & 3,75 & 1,02 & & \\
\hline 10.000 TL and above & 36 & 3,52 & 1,15 & & \\
\hline
\end{tabular}

According to the ANOVA test data, the $p$ value was found to be $0.040<0.05$. According to the data obtained, it has been determined that there is a significant difference between the income level of the participants and their perceived social media performance. When the Tukey test, which was conducted to determine the income variables that caused this difference, was examined; It has been concluded that the Netflix Turkey social media performance perceptions of the participants with an income between $4000 \mathrm{TL}$ and $6000 \mathrm{TL}$ are higher than the other income groups. According to these results, the $\mathrm{H} 5$ hypothesis was confirmed

Table 13. Brand Image and Gender T Test

\begin{tabular}{|c|c|c|c|c|c|}
\hline Gender & $\mathbf{N}$ & Average & Sta. deviation & $\mathbf{T}$ & $\mathbf{P}$ \\
\hline Woman & 184 & 3,84 & 1,26542 & $-1,308$ & $0,192^{*}$ \\
\hline Man & 201 & 3,96 & 1,28463 & & \\
\hline
\end{tabular}

According to the results obtained in Table 13, a significant difference between brand image and gender could not be detected since the $(\mathrm{p})$ value was greater than 0.05 . According to these results, the H6 hypothesis was rejected.

Table 14. Brand Image and Age Groups ANOVA Test

\begin{tabular}{|c|c|c|c|c|c|}
\hline Age & N & Average & Sta. deviation & F & P \\
\hline $18-25$ & 106 & 3,54 & 1,11 & 3,245 & $0,014^{*}$ \\
\hline $25-32$ & 154 & 4,31 & 1,20 & & \\
\hline 32 and above & 125 & 4,11 & 1,08 & & \\
\hline
\end{tabular}


According to the ANOVA test data, the $\mathrm{p}$ value (significance) was found to be $0.014<0.05$. According to these results, it has been determined that there is a significant difference between the age groups of the participants and the brand image. Tukey test was used to determine the significant difference seen in the ANOVA test. According to Tukey test results; It has been concluded that the Netflix Turkey brand image perceptions of the participants in the 25-32 age range are higher than the other age groups. According to these results, the H7 hypothesis was confirmed.

Table 15. Brand Image and Education Status ANOVA Test

\begin{tabular}{|c|c|c|c|c|c|}
\hline Education Status & N & Average & Sta. deviation & F & P \\
\hline High school & 40 & 4,03 & 0,98 & 1,864 & $0,124^{*}$ \\
\hline Associate's degree & 21 & 3,64 & 0,86 & & \\
\hline Bachelor's degree & 233 & 3,81 & 0,94 & & \\
\hline Postgraduate & 91 & 3,86 & 1,03 & & \\
\hline
\end{tabular}

According to the ANOVA test data, the p-value was found to be $0.124>0.05$. According to the data obtained, it was determined that there was no significant difference between the educational status of the participants and the brand image. According to these results, the H8 hypothesis was rejected.

Table 16. Brand Image and Income Level ANOVA Test

\begin{tabular}{|c|c|c|c|c|c|}
\hline Income Level & N & Average & Sta. deviation & F & P \\
\hline 2000 TL and below & 57 & 3,48 & 1,08 & 3,748 & $0,016^{*}$ \\
\hline 2000 TL and 4000 TL & 102 & 3,94 & 0,96 & & \\
\hline 4000 TL and 6000 TL & 105 & 4,17 & 1,03 & & \\
\hline 6000 TL and 8000 TL & 60 & 3,81 & 1,14 & & \\
\hline 8000 TL and 10.000 TL & 25 & 3,76 & 1,17 & & \\
\hline 10.000 TL and above & 36 & 3,49 & 0,98 & & \\
\hline
\end{tabular}

According to the ANOVA test data, the $\mathrm{p}$-value (significance) was found to be $0.016<0.05$. According to the data obtained, it was determined that there was a significant difference between the income level of the participants and the brand image. Tukey test was used to determine the significant difference seen in the ANOVA test. According to Tukey test results; It was concluded that the Netflix Turkey brand image perceptions of the participants with an income between 4,000 TL and 6,000 TL were higher than the participants in the other income group. According to these results, the $\mathrm{H} 9$ hypothesis was confirmed.

\section{Conclusion and Suggestion}

The place of social media, which is the new form of communication in the globalizing world, in our lives has reached an undeniable reality. Businesses that do not ignore the spread of social media users have created profiles for themselves on social media.

Brands that can create their corporate pages through social media platforms can communicate directly with consumers and determine the strategy of brand-related promotional activities through the applications they can develop under these pages.

One of the most significant points that determine brands that develop various strategies to attract the attention of consumers from their competitors; is the image of the brand. Brands that want to be in the minds of consumers can share their messages with consumers through social media applications. These applications, which differentiate goods or services from the point of view of the consumer and make them easy to remember, offer important opportunities to brands and businesses in terms of branding strategies.

With the brand image, consumers develop positive feelings towards the brand. Along with the brand image, consumers' perceptions of the brand shaped. For this reason, businesses need to convey messages that will create the right image for their consumers. In this direction, because of the developments in technology, social media has become an important channel for companies to create the right image and convey the messages they want.

It has been observed that the findings obtained as a result of the analyzes made within the scope of the research give clear answers to the problems of the research. It was concluded that the relationship between perceived 
social media performance and brand image, which is the main problem of the research, is significant and positive. The sub-problems of the research are the examination of Netflix Turkey's social media performance and brand image perception according to the demographic characteristics of the participants. It was concluded that the social media performance perceptions of the participants did not differ according to gender and educational status. It has been concluded that there is a difference in social media performance perceptions according to the age and income status of the participants.

While it is seen that the participants between the ages of 18-25 have the lowest perception of social media performance; Participants aged 32 and over were found to have the highest perception. It has been concluded that the participants aged 32 and over find Netflix Turkey social media accounts more entertaining and interesting than the participants in other age groups. When the relationship between perceived social media performance and income level is examined, it is concluded that the lowest perception is in the participants with an income of $2000 \mathrm{TL}$ and below. As the income level of the participants increased, it was seen that they found Netflix Turkey's social media accounts more entertaining and interesting.

Another sub-problem of the research is to determine the relationship between the brand image perceptions of the participants and their demographic characteristics. It was concluded that the perceptions of the participants regarding the brand image did not differ according to their gender and educational status. While it was concluded that the participants between the ages of 18-25 had the lowest brand image perception; It has been concluded that the participants in the 25-32 age range have a more positive brand image compared to other age groups in Netflix Turkey reminds me of quality and is the leading brand in its category. When the relationship between income level and brand image is examined, it is seen that the lowest brand image perception is in the participants with an income of $2.000 \mathrm{TL}$ and below. It has been concluded that as the income level increases, the perception of brand image changes positively.

It is seen that the H1, H3, H5, H7, and $\mathrm{H} 9$ hypotheses determined within the scope of the study are accepted. Based on these results, it has been concluded that the use of social media is very effective in creating the brand image of enterprises and strengthening the brand image created.

It can be stated that the results of the research are similar to other research results in the literature. Studies aimed at measuring the relationship between perceived social media performance and brand image have shown that there is a positive and meaningful relationship in which similar results emerge.

Considering the increasing importance of the literature review for social media, it can be said that it will affect the brands and the images of the brands in the same direction. At the same time, it can be acted on by taking into account that the studies on perceived social media performance and brand image according to the results of the scales examined together with demographic characteristics differ according to income status and age. In order to positively change the perceptions of users between the ages of 18-25 in terms of Netflix Turkey social media performance and brand image, student package options can be offered to users in this age group. In addition, the content and shares published on social media can be prepared in a way that will attract the attention of the participants in this age group. Since it was concluded that the perception of brand image decreases as the income level decreases as a result of the relationship between income level and brand image, it can be suggested to offer package options that can be used by the participants in the lower income group.

If Netflix Turkey wants to differentiate at the gender and education level for its brand image and perceived social media performance, it can realize different social media strategies on the basis of these demographics. It is possible for participants to talk to other consumers or exchange ideas on Netflix Turkey's social media network. If Netflix Turkey prefers to give the impression that participants can exchange ideas more easily and to give a positive opinion, they can implement studies in this field. The group with the lowest perception of both social media performance and brand image is the group of participants aged 18-25. Based on these, it can be suggested that Netflix Turkey should follow strategies that will positively change both social media performance and brand image perceptions for those in this age group. In addition, it was concluded that the interaction dimension in Netflix Turkey's perceived social media performance scale lags behind other dimensions. It can be stated that one of the most important competitive tools today is to have a good interaction with consumers. Based on this, it can be suggested that Netflix Turkey follow strategies in such a way that mutual interaction with consumers can be more intense and effective in social media accounts and work on this dimension. Opinions of users can be obtained for the shares made on social media. It can be suggested as 
a strategy that will create a positive change on brand image and social media perceptions in order to increase interaction and meet their expectations by being in contact with users by asking what kind of content they want to see and in which direction they browse the posts.

It can be stated that the social media strategies implemented by Netflix Turkey and the resulting brand image show parallels. While the majority of respondents stated that they viewed Netflix Turkey's status as much higher than rival brands, they also stated that they reminded of quality for the perception of brand image. Based on these results, it can be stated that Netflix Turkey's brand image and social media performance are compatible with each other.

For future studies, a wider range of comparisons can be carried out with Netflix Turkey and other rival brands operating on digital platforms. It is thought that the results of this study will shed light on social media practitioners, brands and the work to be carried out thereafter.

\section{REFERENCES}

Aaker, D. (2015). Marka Değeri Yönetimi, Trans: Ender Orfanlı ( Publication date of the original work 1991). Mediacat Yayıncilik.

Aaker, J. L. (1997). Dimensions of brand personality. Journal of Marketing Research, 347-356.

Aaker, J. L., Fournier, S., \& Brasel, S. A. (2004). When good brands do bad. Journal of Consumer Research, 1-16.

Aktepe, C. \& Baş, M. (2008), Marka Bilgisi Sürecinde marka Farkındalığı ve Algıllanan Kalite İlişkisi ve GSM Sektörüne Yönelik Bir Analiz, Gazi Üniversitesi İIBF Dergisi, 10(1), 81-96.

Aktepe, C. \& Ertürk, R. (2020), Sosyal Medyanın Tüketicilerin Satınalma Davranışları Üzerinde Etkisi: Türkiye ve İran'daki Üniversite Öğrencileri Üzerine Bir Uygulama, İşletme Araştırmaları Dergisi, 12(4), 4289-4304.

Akyıldız, S., \& Yılmaz, K. G. Sosyal Medya Konulu Araştırmaların Bilim Haritalama Tekniği ile Bibliyometrik Analizi. OPUS Uluslararası Toplum Araştırmaları Dergisi, 16(28), 1416-1451.

Alselm, K. J., \& Kostelijk, E. (2008). Identity based marketing: A new balanced marketing paradigm. European Journal of Marketing, 907-914.

Esch, F. R. (2008). Brand identity: The guiding star for successful brands. In B. Schmitt \& D. L. Rogers (Eds.), Handbook on brand and experience management. Cheltenham, UK: Edward Elgar.

Faircloth, J. B. (2005). Factors influencing nonprofit resource provider support decisions: applying the brand equity concept to nonprofits. Journal of marketing theory and practice, 1-15.

Fisk, P. (2009). İş Dehası, Trans: Tuğçe Esener( Publication date of the original work 2008). İstanbul: Mediacat Yayınları.

Fournier, S. (1998). Consumers and their brands: Developing relationship theory on consumer research. Journal of Consumer Research, 343-373.

Fournier, S., \& Avery, J. (2011). Putting the 'relationship' back into CRM. Sloan Management Review, 52(3), 6372 .

Fournier, S., Dobscha, S., \& Mick, D. G. (1998). Preventing the premature death of relationship marketing. Harvard Business Review, 76(Jan/Feb), 42-51.

Graham, J. (2008). If there's no brand, there's no business. Canadian Manager, 26(1), pp. 25-27.

Hankinson, G. \& Cowking, P. (2005). Branding in action. Maidenhead: McGraw-Hill.

Hatch, J. M., \& Schutz, M . (2011). Marka Girişimi, Trans: Uğur Mehter . Brandage. 
Hollebeek, L. D. (2011). Demystifying customer brand engagement: Exploring the loyalty nexus. Journal of Marketing Management, 27(7/8), 785-807.

Hsieh, A. T. (2008). The moderating effect of brand image on public relations perception and customer loyalty. Marketing Intelligence \& Planning, 26(1), pp. 26-42.

Hu, Y., Manikonda, L., \& Kambhampati, S. (2014). What we Instagram: A first analysis of Instagram photo content and user types. In Eighth International AAAI Conference on Weblogs and Social Media, (s. (595598)).

Iversen, Nina M., \& Leif E. Hem. (2008). Provenance associations as core values of place umbrella brands: A framework of characteristics. European Journal of Marketing, Vol 42.5/6, p 603-626.

Keller, K. L. (1993). Conseptualizing measuring and managing customer based equity. Journal of Marketing, 57(1), 1-22.

Kotler, P. (2000). Pazarlama yönetimi. Muallimoğlu, N. (Trans.). İstanbul: Beta Yayınları.

Laroche, M, Habibi, R.M \& Richard, M. (2013). To be or not to be in social media: How brand loyalty is affected by social media? International Journal of Information Management, Vol 33, p.76-82.

Liburd, J. (2012). Tourism Research 2.0. Annals of Tourism Research, 39 (2), 883-907.

Okur, H. D., \& Metin, Ö. (2015). Modern iletişimin arayüzü : Sanal iletişim sosyal paylaşım sitelerinin toplumsal ilişki kurma biçimlerine etkisi. Süleyman Demirel Üniversitesi Sosyal Bilimler Esitütüsü Dergisi, (21), 213-46.

Okur, H. D., \& Metin, Ö. (2015). Modern iletişimin arayüzü : Sanal iletişim sosyal paylaşım sitelerinin toplumsal ilişki kurma biçimlerine etkisi. Süleyman Demirel Üniversitesi Sosyal Bilimler Esitütüsü Dergisi, (21), 213-46.

Penni, J. (2017). The future of online social networks (OSN): A measurement analysis using social media tools and application. Telematics and Informatics , 34(5), 498-517.

Rowles, D. (2021, July 17). Digital Branding: A Complete Step-By-Step Guide To Strategy, Tactics, And Measurement, London: Kogan Page, eBook Collection (EBSCOhost). EBSCOhost: http://search.ebscohost.com.ezproxy.metropolia.fi/login.aspx?direct=tr adresinden alındı

Roy, D., \& Banerjee, S. (2007). Caring strategy for integration of brand identity with brand image (s. 140-148). içinde International.

Sheldon, P., \& Bryant, K. (2016). Instagram: Motives for its use and relationship to narcissism and contextual age. Computers in Human Behavior, (58), 89-97.

Sheldon, P., \& Bryant, K. (2016). Instagram: Motives for its use and relationship to narcissism and contextual age. Computers in Human Behavior, (58), 89-97.

Tuten, T. \& Solomon, M. (2014). Social Media Marketing. Essex: Pearson Education Limited. 2-235.

Tolon, M. \& Zengin A.Y. (2016) Bütünleşik Pazarlama İletişimi. Detay Yayınclık, Ankara

Weller, K., Bruns, A., Burgess, J., Mahrt, M., \& P. (2014). Twitter and Society (Digital Formations, 89). New York: Peter Lang.

Wijaya, B. (2013). Dimensions of brand image: A conceptual review from the perspective of brand communication. European Journal of Business and Management, 5(31), 55- 65.

Yanar, K., \& Yılmaz, K. G. (2017). Sosyal medyanın satın alma öncesi ve sonrası tüketici davranışına etkisi üzerine bir araştırma. Yönetim, Ekonomi ve Pazarlama Araştırmaları Dergisi, 1(2), 24-40. 